INDONESIA ACCOUNTING JOURNAL

VOLUME 1, NUMBER 2, YEAR 2019

${ }^{1}$ Corresponding author

Jurusan Akuntansi

Fakultas Ekonomi dan Bisnis

Universitas Sam Ratulangi

Jl. Kampus UNSRAT

Manado, Indonesia, 95115

E-mail: jinnyfert28@gmail.com

${ }^{2,3}$ Jurusan Akuntansi

Fakultas Ekonomi dan Bisnis

Universitas Sam Ratulangi

Jl. Kampus UNSRAT

Manado, Indonesia, 95115

Article info:

Received 20 December 2019

Accepted 20 December 2019

Available online 20 December 2019

Keywords: analysis; regional financial accounting systems; good governanc; financial report; government accounting standards

JEL Classification: $\mathrm{H}_{3}$, M41

DOI: http://doi.org/10.3240o/iaj.26815

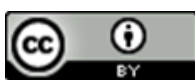

\section{Penerapan sistem akuntansi keuangan daerah pada Badan Perencanaan Penelitian dan Pengembangan di Kabupaten Minahasa Selatan?}

\author{
Jinnyfer Tumbel ${ }^{1}$ \\ Sifrid Sonny Pangemanan ${ }^{2}$ \\ Stanly Alexander ${ }^{3}$
}

\begin{abstract}
Genaral demand for accountability is one of the factor that driven the development of public sector accounting in Indonesia. Government Regulation No. 71 of 2010 concerning Government Accounting Standards explains that government financial reports must provide information that is useful for users. Quality financial reports require an adequate regional financial accounting system, because the system is supporting the creation of transparent and accountable regional financial management. Through the application of the regional financial accounting system, it is expected to be able to carry out its duties and functions so that Good Governance is created. This study used descriptive qualitative research that aims to reveal qualitative information so that it emphasizes the application of regional financial accounting systems and implemented interviews and documentation for getting the data. The results of this study indicate that the application of the regional financial accounting system is in accordance with applicable regulations.
\end{abstract}

\section{Pendahuluan}

Dalam era reformasi ini di setiap negara pasti membutuhkan pemerintahan yang baik atau biasa disebut Good Governance di seluruh dunia, termasuk di Indonesia. Good governance pada dasarnya adalah suatu konsep yang mengacu kepada proses pencapaian keputusan dan pelaksanaannya yang dapat di pertanggungjawabkan secara bersama. Organisasi sektor publik adalah sebuah entitas ekonomi yang menyediakan barang dan/atau jasa publik untuk meningkatkan kesejahteraan masyarakat dan bukan untuk mencari keuntungan finansial (Nordiawan 2010 : 4). Sektor publik adalah sektor ekonomi yang menyediakan berbagai layanan kepada masyarakat. Menurut Sanjaya et al. (2014:2) Pemerintah harus meningkatkan penggunaan informasi keuangan dan pengelolaan keuangan daerah. Untuk mewujudkan hal tersebut maka perlu melakukan reformasi dalam penyajian laporan keuangan, yakni pemerintah harus mampu menyediakan semua informasi keuangan relevan secara jujur dan terbuka kepada publik, karena kegiatan pemerintah adalah dalam rangka melaksanakan amanat rakyat. Laporan keuangan adalah catatan informasi keuangan suatu perusahaan pada suatu periode akuntansi yang dapat digunakan untuk menggambarkan kinerja perusahaan tersebut (SAK, 2009). Nurcholis (2011:42) menjelaskan bahwa melalui sistem pemerintah daerah, pemerintah daerah diberi wewenang untuk mengatur dan mengurus urusan-urusan yang diserahkan kepadanya. Pada dasarnya pemerintah daerah menyusun laporan keuangan dengan menggunakan Sistem Akuntansi Keuangan Daerah yang diharapkan mampu mewujudkan tercapainya transparansi dan akuntabilitas. 
Sistem Akuntansi Keuangan Daerah yaitu serangkaian prosedur mulai dari proses pengumpulan data, pencatatan, sampai dengan pelaporan keuangan, dalam pertanggungjawaban pelaksanaan Anggaran Pendapatan dan Belanja Daerah (APBD) yang dapat dilakukan secara manual atau menggunakan komputer (Permendagri No. 59 Tahun 2007 tentang Penerapan Standar Akuntansi Pemerintah Berbasis Akrual pada Pemerintah Daerah). Akuntansi keuangan daerah memegang peranan penting dalam pengelolaan keuangan daerah agar dapat berjalan sebagaimana mestinya, namun yang menjadi masalah adalah tidak semua masyarakat mengetahui sistem akuntansi keuangan daerah.

\section{Tinjauan pustaka}

Pemerintah Daerah. Menurut Undangundang Nomor 23 tahun 2014 Pasal 1 ayat (2) Pemerintah Daerah adalah penyelenggaraan urusan pemerintahan oleh pemerintah daerah dan dewan perwakilan rakyat daerah menurut asas otonomi dan tugas pembantuan dengan prinsip otonomi seluas-luasnya dalam sistem dan prinsip Negara Kesatuan Republik Indonesia (NKRI), sebagaimana dimaksud dalam Undang-Undang Dasar Negara Republik Indonesia Tahun 1945. Berdasarkan tujuan tersebut, maka dalam Undang-Undang Dasar 1945 pasal 18A, dibentuklah hubungan pemerintah pusat dan daerah yang meliputi : (1) wewenang; (2) keuangan; (3) pelayanan umum; dan (4) pemanfaatan sumber daya alam dan sumber daya lainnya.

Agency Theory (Teori Keagenan). Menurut Belkaoui (2011 : 188), Teori Keagenan berawal dengan adanya kontrak yang timbul di antara berbagai pihak organisasi sebagai suatu solusi yang efisien terhadap konflik kepentingan. Menurut Messier dan Glover (2017 : 7) hubungan keagenan ini mengakibatkan dua permasalahan yaitu : (a) terjadinya informasi asimetris (information asymmetry), dimana manajemen memiliki lebih banyak informasi mengenai posisi keuangan yang sebenarnya dan posisi operasi entitas dibandingkan pemilik; dan (b) terjadinya konflik kepentingan (conflict of interest) konflik akibat ketidaksamaan tujuan, dimana manajemen tidak selalu bertindak sesuai dengan kepentingan pemilik. Pada sektor publik, teori keagenan dipergunakan untuk menganalisis hubungan keagenan antara prinsipal dan agen dalam kaitannya dengan penganggaran sektor publik (Latifah, 2010:85). Untuk mengawasi perilaku pemerintah serta menyelaraskan tujuan rakyat dan pemerintah, maka rakyat mewajibkan pemerintah untuk mempertanggungjawabkan pengelolaan sumber daya yang dipercayakan kepada pemerintah melalui mekanisme pelaporan keuangan secara periodik. Akuntabilitas Publik adalah kewajiban Agen (Pemerintah) untuk mengelola sumber daya, melaporkan, dan mengungkapkan, segala aktivitas dan kegiatan yang berkaitan dengan penggunaan sumber daya publik kepada pemberi mandat (Mahmudi, 2007 : 9).

\section{Sistem akuntansi keuangan daerah}

Pengertian sistem akuntansi keuangan daerah. Akuntansi merupakan aktivitas jasa untuk menyediakan informasi yang diperlukan untuk pengambilan keputusan. Pada sektor publik, pengambilan keputusan terkait dengan keputusan baik pada sektor ekonomi, sosial, dan politik. Menurut Peraturan Menteri Dalam Negeri Nomor 64 Tahun 2013 tersebut, Sistem Akuntansi Pemerintah Daerah atau Sistem Akuntansi Keuangan Daerah (SAKD) merupakan rangkaian sistematik dari prosedur, penyelenggara, peralatan dan elemen lain untuk mewujudkan fungsi akuntansi sejak analisis transaksi sampai dengan pelaporan keuangan di lingkungan organisasi pemerintah daerah. Menurut Erlina (2013 : 6) yang dimaksud dengan sistem akuntansi keuangan daerah adalah sistem akuntansi yang meliputi proses pencatatan, penggolongan, penafsiran, peringkasan transaksi atau kejadian keuangan serta pelaporan keuangan dalam rangka pelaksanaan Anggaran Pendapatan dan Belanja Daerah (APBD). Mulyadi (2014:3) mendefinisikan Sistem Akuntansi adalah organisasi formulir, catatan, dan 
laporan yang dikoordinasi sedemikian rupa untuk menyediakan informasi keuangan yang memudahkan manajemen dalam pengelolaan perusahaan.

Ruang Lingkup Sistem Akuntansi Keuangan Daerah. Menurut Mardi (2011:4), sistem informasi akuntansi dapat diartikan sebagai suatu kegiatan yang terintegrasi yang menghasilkan laporan di bentuk, data transaksi bisnis yang diolah dan disajikan sehingga menjadi sebuah laporan keuangan yang memiliki arti bagi pihak yang membutuhkan. Menurut Peraturan Menteri Dalam Negeri Nomor 64 Tahun 2013 sistem akuntansi keuangan daerah meliputi:

1. Sistem akuntansi Pejabat Pengelola Keuangan Daerah (PPKD). Sistem akuntansi PPKD mencakup teknik pencatatan, pengakuan dan pengungkapan atas pendapatan LO, beban, pendapatan LRA, belanja, transfer, pembiayaan, aset, kewajiban, ekuitas, penyesuaian dan koreksi, penyusunan laporan keuangan PPKD serta penyusunan laporan keuangan konsolidasian pemerintah daerah.

2. Sistem akuntansi SKPD Satuan Kinerja Perangkeat Daerah (SKPD). Sistem akuntansi mencakup teknik pencatatan, pengakuan dan pengungkapan atas pendapatan LO, beban, pendapatan LRA, belanja,aset, kewajiban, ekuitas, penyesuaian dan koreksi serta penyusunan laporan keuangan SKPD.

Pelaporan dan Metode dalam Sistem Akuntansi Keuangan Daerah. Penerapan Akuntansi Keuangan Daerah diatur oleh Peraturan Pemerintah (PP) Nomor 24 Tahun 2005 mengenai Standar Akuntansi Pemerintah, PP Nomor 58 Tahun 2005 mengenai Pengelolaan Keuangan Daerah, dan Peraturan Menteri Dalam Negeri (Permendagri) nomor 13 Tahun 2006. Output yang akan dipakai oleh pihak-pihak berkepentingan terkait akuntansi keuangan daerah adalah: (a) Laporan Realisasi Anggaran; (b) Laporan Neraca; (c) Laporan Arus Kas; (d) Laporan Perubahan Ekuitas Dana; dan (e) Catatan atas Laporan Keuangan.

Metode Pencatatan Akuntansi Keuangan Daerah. Terdapat tiga metode pencatatan dalam Akuntansi Keuangan Daerah, yaitu Single Entry, Double Entry, dan Triple Entry.

\section{Laporan Keuangan Pemerintah Daerah Pengertian Laporan Keuangan.} Menurut Peraturan Pemerintah No.71 Tahun 2010 pengertian laporan keuangan adalah laporan yang terstruktur mengenai posisi keuangan dan transaksi-transaksi yang dilakukan oleh suatu entitas pelaporan. Entitas pelaporan adalah unit pemerintahan yang terdiri dari satu atau lebih entitas akuntansi yang menurut ketentuan peraturan perundang-undangan wajib menyampaikan laporan pertanggungjawaban berupa laporan keuangan yang bertujuan umum, yang terdiri dari: (a) Pemerintah pusat; (b) Pemerintah daerah; (c) Masing-masing kementerian negara atau lembaga dilingkungan pemerintah pusat; dan (d) Suatu organisasi di lingkungan pemerintah pusat/daerah atau organisasi lainnya jika menurut peraturan perundang-undangan satuan organisasi dimaksud wajib menyampaikan laporan keuangan.

Tujuan Laporan Keuangan. Berdasarkan Peraturan Pemerintah No. 71 Tahun 2010, tujuan laporan keuangan sebagai berikut: Pelaporan keuangan pemerintah seharusnya menyajikan informasi yang bermanfaat bagi para pengguna dalam menilai akuntabilitas dan membuat keputusan baik keputusan ekonomi, sosial, maupun politik dengan: (a) menyediakan informasi tentang sumber, alokasi dan penggunaan sumber daya keuangan; (b) menyediakan informasi mengenai kecukupan penerimaan periode berjalan untuk membiayai seluruh pengeluaran; (c) menyediakan informasi mengenai jumlah sumber daya ekonomi yang digunakan dalam kegiatan entitas pelaporan serta hasil-hasil yang telah dicapai; (d) menyediakan informasi mengenai bagaimana entitas pelaporan mendanai seluruh kegiatannya dan mencukupi kebutuhan kasnya; (e) menyediakan informasi mengenai posisi keuangan dan kondisi entitas pelaporan berkaitan dengan sumber-sumber penerimaannya, baik jangka 
pendek maupun jangka panjang, termasuk yang berasal dari pungutan pajak dan pinjaman; dan (f) menyediakan informasi mengenai perubahan posisi keuangan entitas pelaporan, apakah mengalami kenaikan atau penurunan, sebagai akibat kegiatan yang dilakukan selama periode pelaporan.

\section{Komponen Laporan Keuangan.} Berdasarkan Peraturan Pemerintah No. 71 Tahun 2010, komponen laporan keuangan adalah komponen-komponen yang terdapat dalam satu set laporan keuangan terdiri dari laporan pelaksanaan anggaran (budgetary reports) dan laporan finansial, sehingga seluruh komponen menjadi sebagai berikut:

(a) Laporan Realisasi Anggaran; (b) Laporan Perubahan Saldo Anggaran Lebih; Neraca; (d) Laporan Operasional; (e) Laporan Arus Kas; (f) Laporan Perubahan Ekuitas; dan (g) Catatan atas Laporan Keuangan.

Fungsi Laporan Keuangan. Laporan keuangan disusun untuk menyediakan informasi yang relevan mengenai posisi keuangan dan seluruh transaksi yang dilakukan oleh suatu entitas pelaporan selama satu periode pelaporan. Fungsi laporan keuangan tersebut diuraikan sebagai berikut:

a. Akuntabilitas. Mempertanggungjawabkan pengelolaan sumber daya serta pelaksanaan kebijakan yang dipercayakan kepada entitas pelaporan dalam mencapai tujuan yang telah ditetapkan secara periodik.

b. Manajemen. Membantu para pengguna untuk mengevaluasi pelaksanaan kegiatan suatu entitas pelaporan dalam periode pelaporan sehingga memudahkan fungsi perencanaan, pengelolaan dan pengendalian atas seluruh aset, kewajiban, dan ekuitas pemerintah untuk kepentingan masyarakat.

c. Transparansi. Memberikan informasi keuangan yang terbuka dan jujur kepada masyarakat berdasarkan pertimbangan bahwa masyarakat memiliki hak untuk mengetahui secara terbuka dan menyeluruh atas pertanggungjawaban pemerintah dalam pengelolaan sumber daya yang dipercayakan kepadanya dan ketaatannya pada peraturan perundangundangan.

d. Keseimbangan Antargenerasi (intergenerational equity). Membantu para pengguna dalam mengetahui kecukupan penerimaan pemerintah pada periode pelaporanuntuk membiayai seluruh pengeluaran yang dialokasikan dan apakah generasi yang akan datang diasumsikan akan ikut menanggung beban pengeluaran tersebut.

e. Evaluasi Kinerja. Mengevaluasi kinerja entitas pelaporan, terutama dalam penggunaan sumber daya ekonomi yang dikelola pemerintah untuk mencapai kinerja yang direncanakan.

Adapun empat karakteristik berikut ini merupakan prasyarat normatif yang diperlukan agar laporan keuangan pemerintah dapat memenuhi kualitas yang dikehendaki. Karakteristik atas laporan keuangan tersebut diuraikan sebagai berikut:

1. Relevan. Laporan keuangan bisa dikatakan relevan apabila informasi yang termuat di dalamnya dapat mempengaruhi keputusan pengguna dengan membantu mereka mengevaluasi peristiwa masa lalu atau masa kini, dan memprediksi masa depan, serta menegaskan atau mengoreksi hasil evaluasi mereka di masa lalu. Dengan demikian, informasi laporan keuangan yang relevan dapat dihubungkan dengan maksud penggunaannya. Informasi yang relevan: (a) memiliki manfaat umpan balik (feedback value); (b) memiliki manfaat prediktif (predictive value); (c) tepat waktu; dan (d) lengkap.

2. Andal. Informasi dalam laporan keuangan bebas dari pengertian yang menyesatkan dan kesalahan material, menyajikan setiap fakta secara jujur, serta dapat diverifikasi. Informasi yang andal memenuhi karakteristik : (a) penyajian jujur; (b) dapat diverifikasi (verifiability); dan (c) netralitas.

3. Dapat dibandingkan.

4. Dapat dipahami. 


\section{Metode penelitian}

Jenis Penelitian. Penelitian ini adalah penelitian kualitatif deskriptif yaitu penelitian yang bertujuan untuk mengungkapkan informasi kualitatif sehingga lebih menekankan pada proses bagaimana penerapan sistem akuntansi keuangan daerah.

Jenis Data. Jenis data yang digunakan yaitu data kualitatif deskriptif, merupakan salah satu dari jenis penelitian yang termasuk dalam jenis penelitian kualitatif. Adapun tujuan dari penelitian ini adalah untuk mengungkapkan kejadian atau fakta, keadaan, fenomena, variabel dan keadaan yang terjadi saat penelitian berlangsung dengan menyuguhkan apa yang sebenarnya terjadi.

Sumber Data. Penelitian ini menggunakan data primer. Data primer yaitu data yang diperoleh dengan cara melakukan penelitian langsung ke lapangan guna memperoleh atau mengumpulkan keterangan untuk selanjutnya diolah sesuai kebutuhan penelitian. Dalam penelitian ini, data primer yang digunakan adalah hasil riset dengan beberapa orang pelaksana yang berada pada bagian perencanaan dan keuangan kantor BAPELITBANG Kabupaten Minahasa Selatan yaitu Kepala sub bagian (Kasubag) Perencanaan dan Keuangan. Data yang digunakan dalam penelitian ini antara lain :Sejarah singkat tempat penelitian, struktur organisasi, sistem penerapan Akuntansi Keuangan daerah dan Laporan keuangan pada BAPELITBANG Kabupaten Minahasa Selatan.

Prosedur Penelitian. Berikut langkahlangkah untuk menganalisis data sesuai dengan tujuan penelitian:

1. Tahap pengumpulan data, tahap awal dari analisis data adalah pengumpulan data yang akan dianalisis, yaitu data yang diperoleh melalui wawancara dan dokumentasi mengenai penerapan sistem akuntansi keuangan daerah di BAPELITBANG Minahasa Selatan.

2. Tahap Editing, adalah proses pemeriksaan kejelasan dan kelengkapan terkait pengisian instrumen pengumpulan data, yaitu data berupa hasil wawancara, visi dan misi perusahaan, sejarah instansi, struktur organisasi, dan sistem akuntansi keuangan daerah.

3. Tahap Koding, merupakan proses identifikasi dan klasifikasi terhadap semua pernyataan yang ada pada instrumen pengumpulan data berdasarkan variabel yang sedang diteliti, yaitu bagaimana sistem akuntansi keuangan daerah dan kualitas laporan keuangan pada BAPELITBANG Minahasa Selatan.

4. Tabap Membuat Konsep, setelah hasil koding menunjukkan bagaimana penerapansistem akuntansi keuangan daerah pada Badan Perencanaan Penelitian Dan Pengembangan di Kabupaten Minahasa Selatan maka hasil koding tersebut dapat dijadikan konsep.

5. Tahap Memperoleh Hasil Penelitian, ditahap ini peneliti akan mengkonfirmasi teori yang sudah ada, mengembangkan teori atau membuat teori baru. Hasil analisis tersebut merupakan hasil yang siap dipresentasikan kepada publik bahwa memang benar dalam prakteknya penerapan sistem akuntansi keuangan daerah harus sudah transparan dan akuntabilitas.

\section{Hasil analisis dan pembahasan}

\section{Hasil analisis}

Prosedur Pengelolaan Keuangan Daerah Dalam Rangka Penerapan Sistem Akuntansi Keuangan Daerah. Pengelolaan Keuangan Daerah Bapelitbang Kabupaten Minahasa Selatan dilakukan oleh bagian Perencanaan dan Keuangan. Penerapan penyusunan anggaran berdasarkan kinerja yang menggambarkan klasifikasi anggaran berdasarkan kegiatan dan fungsi dasar pengelolaan keuangan BAPELITBANG Kabupaten Minahasa Selatan adalah penyusunan APBD Kabupaten Minahasa Selatan. APBD merupakan penjabaran dari semua Dokumen Pendapatan Anggaran (DPA) perangkat Daerah termasuk BAPELITBANG. DPA BAPELITBANG Kabupaten Minahasa Selatan memuat 
anggaran kas yang dibagi menjadi program kegiatan dan dilaksanakan setiap triwulan. Setiap triwulan ada program kegiatan dan anggaran yang harus dilaksanakan, pelaksanaan kegiatan-kegiatan dimaksud. Berdasarkan anggaran-anggaran kas tersebut BAPELITBANG melakukan permohonan Surat Permintaan Dana (SPD), setelah disetujui oleh dinas keuangan daerah maka dapat diajukan Surat Perintah Membayar (SPM). Berdasarkan tindak lanjut dari dinas keuangan daerah dalam bentuk SP2D (Surat perintah permintaan dana) dengan SPJ (surat Pertanggungjawaban/administrasi) sesuai dengan kegiatan yang dilaksanakan contoh kegiatan rapat jadi SPJ yang dipersiapkan berupa undangan, dokumentasi kegiatan rapat, notulen rapat, dokumentasi makan minum rapat. Setiap triwulan bahkan setiap semester juga berlaku seperti itu mekanismenya permintaan pembayaran berdasarkan kegiatan-kegiatan yang sudah dilaksanakan. Lebih jelasnya Prosedur Pengelolaan dan Penyusunan Keuangan Daerah seperti pada bagan alur dibawah ini :

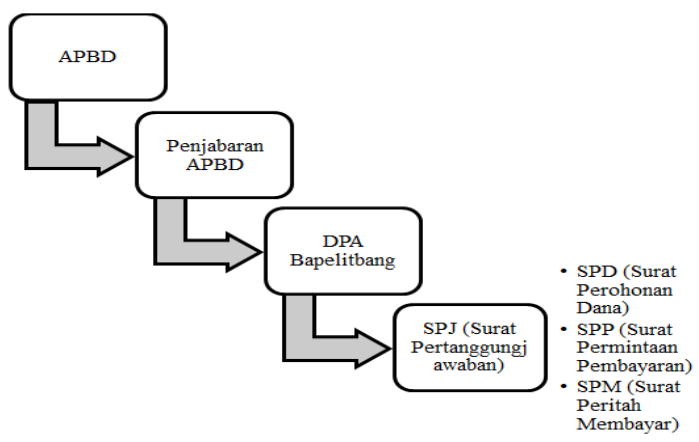

Gambar 1. Siklus Prosedur Pengelolaan
dan Penyusunan Keuangan Daerah
Sumber data: Bapelitbang Kabupaten Minahasa Selatan

\section{Penerapan Pengelolaan Keuangan BAPELITBANG di Kabupaten} Minahasa Selatan. Badan Perencanaan Penelitian dan Pengembangan Kabupaten Minahasa Selatan dalam pelaporan keuangan Daerah saat ini telah berpedoman pada Peraturan Pemerintah Nomor 71 Tahun 2010 tentang Standar Akuntansi Pemerintahan yang dijabarkan dalam Peraturan Menteri Dalam Negeri Nomor 64 Tahun 2013 dengan melaksanakan tata usaha keuangan daerah dengan pedoman Sistem dan Prosedur Penatausahaan dan Akuntansi, Pelaporan dan Pertanggungjawaban keuangan daerah yang terdiri dari Laporan Arus Kas, Laporan Realisasi/ Perhitungan APBD, Neraca, dan Perhitungan Anggaran. Pemerintah Kabupaten Minahasa Selatan dalam hal ini Bapelitbang membuat Laporan Realisasi Fisik Keuangan setiap bulan untuk mengetahui pencapaian realisasi fisik maupun keuangan yang menjadi dasar penyusunan laporan keuangan Bapelitbang pada akhir tahun anggaran. Dalam hal penyusunan laporan keuangan keuangan, Bapelitbang selaku Perangkat Daerah hanya membuat Laporan Realisasi Anggaran (LRA), Neraca dan Catatan Atas Laporan Keuangan (CALK). Salah satu unsur penting dalam neraca adalah aset daerah. Aset daerah adalah seluruh kekayaan yang dimiliki, dikuasai dan menjadi hak daerah. Setelah neraca awal tersusun Pemerintah BAPELITBANG menerapkan sistem akuntansi keuangan daerah dengan menggunakan komputerisasi. Sehingga setiap transaksi yang sudah terjadi dicatat sesuai dengan metode pencatatan yang digunakan dalam sistem akuntansi keuangan daerah. Dalam Sistem Akuntansi Keuangan Daerah diidentifikasi dengan kode rekening, dan pembentukan kode rekening ini merupakan bagian yang paling menentukan ketika suatu daerah ingin menerapkan sistem akuntansi keuangannya. Dengan demikian diperlukan suatu cara untuk mengkonvrensi kode rekening dalam Sistem Akuntansi Keuangan Daerah. Selain itu dalam setiap penerepan sistem bisa dilakukan dengan cara lain dimana sistem yang baru menggantikan sistem yang lama. Oleh karena itu diperlukan suatu cara konvensi yang akan menjadi jembatan dari manual menuju sistem akuntansi keuangan daerah. BAPELITBANG Kabupaten Minahasa Selatan telah menggunakan suatu aplikasi bernama Kasda Online yang merupakan suatu sistem yang memungkinkan pengelola kas daerah dapat berinteraksi langsung dengan sistem yang ada di bank daerah secara terpadu. Dengan Modul Kasda 
Terpadu bendahara umum daerah dapat melakukan transaksi pemindahbukuan dan melihat mutasi rekening kas daerah secara tepat waktu.

Pelaksanaan Administrasi Keuangan Daerah dalam Sistem Pencatatan. Metode pencatatan yang digunakan oleh Pemerintah BAPELITBANG Kabupaten Minahasa Selatan sebelum tahun 2018 adalah basis kas.Hal ini sesuai dengan sistem administrasi keuangan yang dianut dinegara Indonesia, sehingga BAPELITBANG Kabupaten Minahasa Selatan pun tunduk kepada peraturan-peraturan yang ada, termasuk peraturan tentang administrasi keuangannya. BAPELITBANG Kabupaten Minahasa Selatan juga telah melakukan sistem non tunai dimana sistem ini berbeda dengan sistem tunai. Contohnya dalam sistem tunai pencairan dana melalui bendahara tetapi pada sistem non tunai pencairan dana dilakukan langsung pada rekening masing-masing pihak ketiga. Sistem ini mewujudkan suatu sistem yang lebih transparan dan akuntabel dan dengan menggunakan sistem ini lebih meminimalisir terjadinya penyimpangan-penyimpangan. Berdasarkan pengamatan dan wawancara dengan Kepala Sub Bagian, maka dapat diidentifikasi bahwa penerapan sistem administrasi keuangan daerah basis acrual yang lebih sering disebut dengan Sistem Akuntansi Pemerintahan (SAP) Daerah basis acrual (PP No 71 Tahun 2010) sudah dilakukan oleh pemerintah BAPELITBANG Kabupaten Minahasa Selatan saat ini. Pemerintah BAPELITBANG Kabupaten Minahasa Selatan dipandang sebagai salah satu pemerintah daerah yang terbuka terhadap perubahan dan cepat melaksanakan suatu peraturan perundang-undangan yang akan membawa dampak baik bagi pelayanan pemerintah kepada publik atau masyarakat. Dapat dinilai bahwa pengelolaan Keuangan Daerah yang tertib, taat pada peraturan perundang-undangan yang berlaku, transparan dan bertanggung jawab sudah cukup baik dilakukan BAPELITBANG Kabupaten Minahasa Selatan.

\section{Pembahasan}

Prosedur pengelolaan keuangan daerah dalam rangka penerapan Sistem Akuntansi Keuangan Daerah. Secara umum prosedur pengelolaan keuangan daerah yang ditetapkan oleh Pemerintah BAPELITBANG Kabupaten Minahasa Selatan sesuai dengan prosedur yang ditetapkan oleh peraturan perundangundangan yang berlaku mengenai keuangan daerah. Pemerintah BAPELITBANG Kabupaten Minahasa Selatan merupakan suatu badan yang cepat menanggapi perubahan-perubahan aturan, dengan maksud untuk kelancaran kegiatan dan meningkatkan tugas dan tanggung jawab pelayanan kepada masyarakat. Berdasarkan pengamatan dan wawancara yang dilakukan dengan Kepala bagian Perencanaan dan Keuangan serta beberapa staf pegawai Bagian Keuangan Pemerintah BAPELITBANG Kabupaten Minahasa Selatan,dinilai bahwa prosedur yang dilaksanakan oleh Pemerintah BAPELITBANG Kabupaten Minahasa Selatan sudah cukup memadai dapat dilihat dari hal-hal sebagai berikut :

a. Terdapat pembagian tugas dan wewenang dalam pelaksanaan administrasi keuangan daerah. Suatu sistem yang baik harus bisa memisahkan setiap tugas dan tanggung jawab agar tidak terjadi duplikasi dan tidak terjadi suatu penyimpangan karena adanya tugas-tugas yang duplikasi atau tugas-tugas yang seharusnya dikerjakan oleh lebih dari satu orang tetapi dikerjakan oleh satu orang terutama tugas-tugas yang strategis seperti tugas seorang otorisator dengan seorang koordinator yang dirangkap oleh satu orang sehingga terjadi ketidakindependenan dalam pengambilan keputusan serta rawan terhadap penyimpangan. Pembagian tugas dan wewenang diperlukan agar terjadi suatu kontrol yang baik dalam setiap tindakan yang dilakukan oleh setiap bagian atau setiap orang.

b. Adanya review berjenjang dalam pemberian persetujuan atas suatu transaksi. Review ini bertujuan untuk memperoleh pengesahan sehingga suatu masalah 
harus ditelaah atau suatu transaksi diketahui oleh semua pimpinan yang berwenang sehingga kesalahan persetujuan bukan hanya tanggung jawab perorangan. Selain itu juga review berjenjang ini berguna untuk saling mengontrol suatu masalah yang akan ditelaah atau disetujui jika ada suatu pertimbangan yang terlewat oleh seseorang yang menduduki jabatanjabatan dibawahnya maka bisa diperbaiki oleh seseorang yang menduduki jabatan setingkat lebih tinggi, demikian seterusnya. Berdasarkan pengamatan yang dilakukan, review berjenjang yang dilakukan oleh Pemerintah BAPELITBANG Kabupaten Minahasa Selatan memang kompleks, namun hal ini dimaksudkan agar pimpinan mengetahui secara pasti dan detail setiap transaksi yang ada dilingkungan kerjanya. Hal ini menjadi suatu kontrol yang cukup baik bagi pimpinan sehingga bisa melakukan efisiensi dalam setiap pengadaan atau kegiatan-kegiatan yang dilakukan oleh setiap satuan kerja dilingkungan Pemerintah BAPELITBANG Kabupaten Minahasa Selatan.

c. Adanya proses Pengendalian manajemen, termasuk manajemen keuangan. Dalam suatu organisasi atau lembaga, manajemen harus mempunyai fungsi perencanaan, pengorganisasian dan pengendalian. Dengan perencanaan yang diorganisasikan secara tepat dan diikuti dengan pengendalian yang nyata maka suatu organisasi bisa dinilai keberhasilannya. Dengan perencanaan maka dapat dinilai bahwa Pemerintah BAPELITBANG Kabupaten Minahasa Selatan termasuk salah satu pemerintah daerah memiliki manajemen pemeritahan cukup baik. Dari sisi pengorganisasian, Pemerintah BAPELITBANG Kabupaten Minahasa Selatan telah menetapkan prosedurprosedur kegiatan yang cukup baik.

Penerapan Pengelolaan Keuangan dalam Sistem Akuntansi Keuangan Daerah Pemerintah BAPELITBANG
Kabupaten Minahasa Selatan menetapkan Sub Bagian yang harus mempertanggungjawabkan untuk mengelola dan mengoperasikan data yang ada pada sub bagian masing-masing. Dengan kondisi seperti ini Pemerintah BAPELITBANG Kabupaten Minahasa Selatan bisa dikatakan mempunyai sumber daya/sarana prasarana sudah cukup memadai untuk penerapan Sistem Akuntansi Keuangan Daerah yang memang dirancang untuk menggunakan sistem komputerisasi. Dengan demikian Pemerintah BAPELITBANG Kabupaten Minahasa Selatan menerapkan Sistem Akuntansi Keuangan Daerah berbasis akrual yang memang menggunakan suatu program komputer (software) yang bisa dilakukan dengan cara lebih cepat karena didukung oleh operator yang cukup baik dan sarana prasarana yang memadai.

Administrasi Keuangan Daerah dalam Sistem Pencatatan. Standar adalah acuan yang jelas dan bagus untuk dijadikan sebagai pedoman pelaksanaan suatu kegiatan termasuk kegiatan administrasi keuangan. Standar juga merupakan tolak ukur kesesuaian antara prinsip dan praktek. Namun kadangkala standar lambat ditetapkan sementara praktek harus dilaksanakan. Oleh karena itu Pemerintah BAPELITBANG Kabupaten Minahasa Selatan mencoba menerapkan Sistem Akuntansi Keuangan Daerah, berdasarkan sistem yang dihasilkan oleh Tim Kelompok Kerja Evaluasi dan Informasi Keuangan Daerah yang diantaranya mempunyai tugas menyusun rancangan standar akuntansi keuangan pemerintah daerah. Sistem Akuntansi Keuangan Daerah Pemerintah BAPELITBANG Kabupaten Minahasa Selatan ini setelah di evaluasi, maka dinilai bahwa setiap komponen dan substansi Laporan Keuangan yang dibuat telah sesuai berdasarkan Peraturan Pemerintah No. 71 Tahun 2010 serta Pemendagri Nomor 64 Tahun 2013. Berdasarkan hasil pengamatan dan wawancara dengan kepala sub bagian keuangan BAPELITBANG Kabupaten Minahasa Selatan, menyebutkan bahwa suatu laporan keuangan dikatakan berkualitas jika telah mewujudkan 
transparansi dan akuntabilitas dalam pelaporan keuangannya. Salah satu upaya konkret untuk mewujudkan transparansi dan akuntabilitas pengelolaan keuangan adalah penyampaian laporan pertanggungjawaban keuangan pemerintah yang memenuhi prinsip-prinsip tepat waktu dan disusun dengan mengikuti standar akuntansi pemerintah yang telah diterima secara umum.

\section{Kesimpulan dan saran Kesimpulan}

Berdasarkan hasil dan pembahasan yang telah diuraikan pada bab sebelumnya,maka dapat disimpulkan bahwa sistem dan prosedur keuangan di BAPELITBANG Kabupaten Minahasa Selatan sesuai dengan peraturan yang ada, yaitu meningkatkan kinerja transparansi dan akuntabilitas dalam pengelolaan keuangan daerah, melalui pengamatan dapat dilihat bahwa BAPELITBANG Kabupaten Minahasa Selatan menerapkan sistem dan prosedur yang baik yaitu terdapat pembagian tugas dan wewenang dalam pelaksanaan administrasi keuangan daerah, adanya review berjenjang dalam pemberian persetujuan atas suatu transaksi, serta adanya proses pengendalian manajemen termasuk manajemen keuangan. Dengan adanya Pencatatan Sistem Akuntansi Keuangan Daerah berdasarkan Pemendagri No. 64 Tahun 2013 dan Peraturan Pemerintah No. 71 Tahun 2010 tentang pencatatan dan pelaporan keuangan berbasis akrual yang memang menggunakan suatu program komputer (software) membuat akses terhadap laporan dan data keuangan menjadi lebih cepat dan transparan.

Saran

Berdasarkan kesimpulan diatas, penulis menyarankan hal-hal sebagai berikut :

1. Untuk meningkatkan kepercayaan rakyat terhadap di BAPELITBANG Kabupaten Minahasa Selatan serta bisa mewujudkan Sistem Keuangan Daerah yang transparansi dan akuntabilitas, maka harus menggunakan sumber daya yang berpotensi dan mempunyai keahlian dalam bidangnya agar bisa lebih baik dan berjalan lancar.

2. Penelitian selanjutnya disarankan untuk menambah tahun pengamatan sehingga hasil yang diperoleh lebih dapat dijadikan dasar pengambilan keputusan bagi pemerintah dalam Sistem Akuntansi Keuangan Daerah.

\section{Daftar pustaka}

Belkaoui, A, R. (2011). Accounting theory. Edisi Kelima. Jakarta: Salemba Empat.

Erlina, R. (2013). Akuntansi keuangan daerah berbasis akrual.Medan: Brama Ardian.

Ikatan Akuntan Indonesia. 2009. Standar akuntansi keuangan, PSAK No.1: penyajian laporan keuangan. Jakarta: Salemba Empat.

Latifah, N, P. (2010). Adakah Perilaku Oportunistik dalam Aplikasi Agency Theory di Sektor Publik? Fokus Ekonomi 5(2), 85-94. https://www.academia.edu/23599910/ADAKA H_PERILAKU_OPORTUNISTIK_DALAM_ APLIKASI_AGENCY_THEORY_DI_SEKTO R_PUBLIK_Is_There_of_Opportunistic_Behav ior_on_the_Agency_Theory_Aplication_in_the Public_Sector

Mahmudi.(2007). Manajemen kinerja sektor publik. Yogyakarta: Sekolah Tinggi Ilmu Manajemen YKPN.

Mardi. (2011). Sistem informasi akuntansi. Bogor: Ghalia Indonesia.

Messier, W. F \& Glover, S. M. (2017). Jasa audit dan assurance. Jakarta: Salemba Empat.

Mulyadi. (2014). Sistem akuntansi. Cetakan Keempat. Jakarta: Salemba Empat.

Nordiawan, D. \& Ayuningtyas, H. (2010). Akuntansi sektor publik. Edisi Kedua. Jakarta: Salemba Empat.

Nurcholis, H. (2011). Pertumbuhan \& penyelenggaraan pemerintahan desa. Jakarta: Erlangga.

Peraturan Pemerintah Nomor 71 Tahun 2010 tentang Standar akuntansi pemerintah.

Permendagri Nomor 59 Tahun 2007 tentang Sistem akuntansi keuangan daerah.

Peraturan Menteri Dalam Negeri Nomor 64 Tahun 2013 tentang Penerapan Standar Akuntansi Pemerintahan berbasis Akrual pada Pemerintah Daerah.

Sanjaya, K. P., Edy, S., \& Erni, S. (2014). Pengaruh penyajian laporan keuangan daerah dan aksesibilitas laporan keuangan daerah terhadap penggunaan informasi keuangan daerah. Jurnal Ekonomi, 2(1). 1-12. https://ejournal.undiksha.ac.id/index.php/S1ak /article/viewFile/4130/3251

Undang-Undang Republik Indonesia Nomor 23 tahun 2014 tentang Pemerintah Daerah. Lembaran Negara Republik Indonesia Tahun 2014 Nomor 244. Jakarta. 